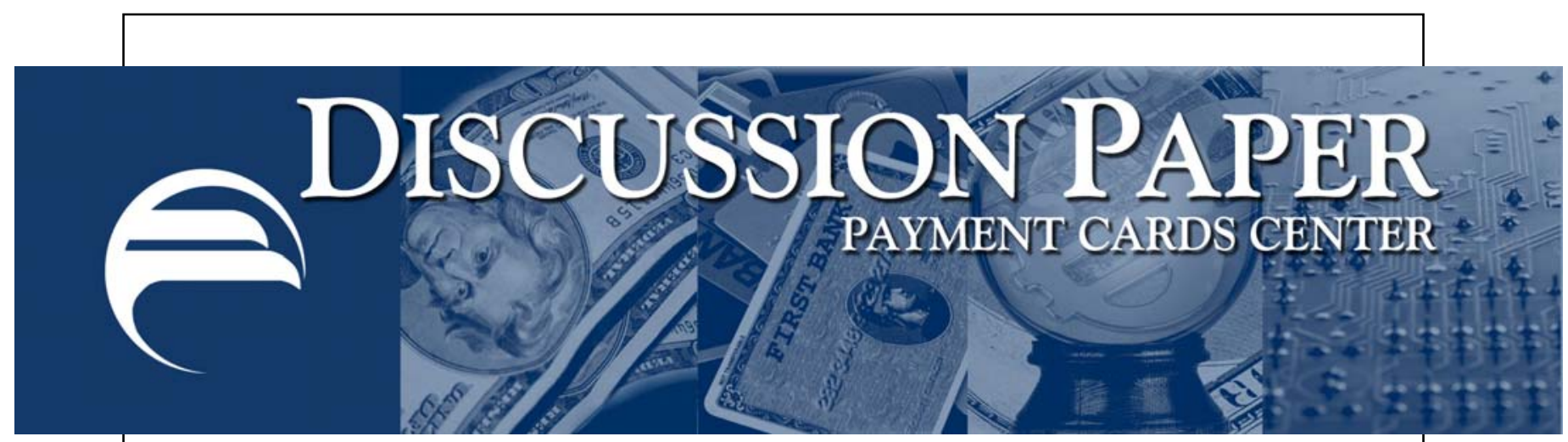

\title{
The Laws, Regulations, Guidelines, and Industry Practices That Protect Consumers Who Use Gift Cards
}

\section{Philip Keitel}

July 2008

Summary: This paper discusses consumer protections available to gift-card users. Specifically, it examines the ways in which value loaded at the time of purchase is protected for future card use or returned to consumers when the card is not used or has expired. The consumer protection information included in this paper is derived from a number of sources, including several types of state statutes, Federal Trade Commission decisions, financial industry regulatory agency guidelines, and previous interviews with payments industry experts regarding practices concerning networkbranded gift cards. This paper expands research begun by the Payment Cards Center in 2004 into prepaid cards generally and the protections available to consumers who use gift cards specifically.

* Payment Cards Center, Federal Reserve Bank of Philadelphia, Ten Independence Mall, Philadelphia, PA 19106. E-mail: philip.keitel@phil.frb.org. Thanks to Amelia Boss and Judith Rinearson, Partner, Bryan Cave LLP. The views expressed here are not necessarily those of this Reserve Bank or of the Federal Reserve System. Summaries of laws and guidelines contained herein are for discussion purposes only and are not to be relied on for adjudicative purposes.

\section{FEDERAL ReserVE BANK OF PHILADELPHIA}




\section{Introduction}

When today's consumers arrive at a retail checkout counter, they typically have a number of cardbased payment options. They can reach for a signature-debit card, a PIN-debit card, a credit card, or a prepaid card, commonly in the form of a gift card. Although most consumers today are familiar with the way gift cards work and have purchased at least one gift card for themselves or someone else, it is unlikely that many consumers understand how the value they load at the time the card is purchased is protected from the imposition of excessive or immediate fees, is maintained for future card use, or is returned when the card is no longer used or has expired. And while consumers who use credit and debit cards enjoy well-recognized protections under the laws, regulations, and industry practices that govern the use of these instruments, ${ }^{1}$ the laws, regulations, guidelines, and industry practices that protect consumers who use gift cards are still evolving.

Generally, this evolution involves two fundamental types of gift card: closed-loop cards and open-loop cards. ${ }^{2}$ Closed-loop cards are typically sold by individual retailers, are serviced by those retailers (or their agents), and function only at the selling retailer's locations. Closed-loop cards account for both the majority of gift cards sold and the majority of dollars loaded onto gift cards. Examples of commonly recognized closed-loop cards include the Best Buy gift card ${ }^{3}$ and the Starbucks card. ${ }^{4}$ Compared with closed-loop gift cards, open-loop gift cards have fewer limitations on their use. Open-loop cards are ordinarily issued by a financial institution, operate over debit or credit card networks (frequently

\footnotetext{
${ }^{1}$ See Mark Furletti and Stephen Smith, "The Laws, Regulations, and Industry Practices That Protect Consumers Who Use Electronic Payment Systems: Credit and Debit Cards,” Federal Reserve Bank of Philadelphia Payment Cards Center Discussion Paper (January 2005). This paper describes protections available to consumers who use credit and debit cards.

${ }^{2}$ For the purposes of this analysis, recent innovations in prepaid card processing technology that enable networkbranded gift cards to function over traditional payment networks but limit usability to a particular set of merchants, thereby blurring some of the traditional distinctions drawn between closed-loop and open-loop gift-card models and creating gift-card products that can be characterized as semi-open-loop cards, semi-closed-loop cards, or simply as "multimerchant gift cards," will be treated as open-loop products. See, for example, Judith Rinearson and Chris Woods, "Beware Strangers Bearing Gift Cards, Some Wholesome Advice for Your Retail Clients," Business Law Today, 14:2 (November/December 2004). This paper differentiates among four types of models for prepaid card products, including "semi-open" and "semi-closed" models, which, taken together, encompass gift-card programs. See also Amy McCullough, "Merchants Market Themselves by Sharing Cards,” Prepaid Trends, 3:10 (May 21, 2008), pp. 1 and 5. This paper distinguishes "multimerchant" gift cards from open-loop gift cards.

${ }^{3}$ See www.bestbuy.com/olspage.jsp?type=category\&id=cat09000, for more information on Best Buy gift cards.

${ }^{4}$ See www.starbucks.com/card/buyacard_style.asp, for more information on the Starbucks card.
} 
open-loop cards carry a network logo, such as Visa, MasterCard, American Express, or Discover), and can be used at a wider array of retail locations than closed-loop cards. Typically, open-loop gift cards may be used everywhere that displays the payment network logo with which they are branded. Examples of network-branded open-loop gift cards issued by financial institutions include the American Express gift card, ${ }^{5}$ the National City Visa gift card, ${ }^{6}$ and the KeyBank Key Possibilities MasterCard gift card. ${ }^{7}$

Additionally, some open-loop cards are reloadable; that is, the consumer can load additional value after making a purchase that depletes the original stored value. Moreover, some open-loop cards, such as the ATM gift card from GiftCards.com, can be used to obtain cash from ATMs or redeemed for cash at merchant locations. ${ }^{8}$ Although sales of open-loop gift cards and amounts loaded onto open-loop gift cards are growing, industry analysts estimate that fewer dollars are loaded onto open-loop gift cards than closed-loop cards. ${ }^{9}$

The analysis that follows explores only those consumer gift-card protections related to the gift cards' main feature: the pay-now, buy-later feature. In focusing only on the pay-now, buy-later feature, this paper highlights the ways in which payments made at the time of purchase or during card reloads are protected from surprise reduction or expiration or are refunded to consumers when the card is no longer used. This paper does not address the many laws and regulations that may be broadly considered to protect consumers but which do not directly govern consumers' ordinary use of their gift cards or the return of value loaded at the time the card is purchased. ${ }^{10}$

\footnotetext{
${ }^{5}$ See www10.americanexpress.com/sif/cda/page/0,1641,22224,00.asp?us_nu=leftnav.

${ }^{6}$ See https://giftcard.nationalcity.com/index.cfm?pageid.

${ }^{7}$ See www.key.com/html/H-8.html.

${ }^{8}$ See www.giftcards.com/consumer/atm.html.

${ }^{9}$ See "Load on All Cash Access Segments for Network Branded Prepaid, Open Gift Card Segment," Mercator Advisory Group, 2007. This publication estimates that \$3 billion of value was loaded onto open-loop gift cards in 2006. This can be compared with closed-loop card sales noted in footnote 12 .

${ }^{10}$ These include operative provisions (or potentially operative provisions) of state laws, including money services business and money transmitter licensing laws, bankruptcy laws (some states give priority status among unsecured creditors to gift cardholders of a bankrupt retailer), and the Uniform Money Services Act; and federal laws, including the Bank Secrecy Act, the USA PATRIOT Act, the Gramm-Leach-Bliley Act, the Office of Foreign Asset Control list, federal money services business regulations, Financial Crimes Enforcement Network regulations, customer identification requirements codified in 31 C.F.R. § 103.121 (2003), and the Fair and Accurate Credit Transactions Act.
} 
Ultimately, the goal of this paper is to provide a better understanding of the interrelated processes by which laws, regulations, agency guidelines, and industry practices protect consumers who purchase and use gift cards. As consumers' use of electronic payments grows ${ }^{11}$ and sales of gift cards rapidly increase, ${ }^{12}$ understanding how these systems function and how consumers who use these instruments are protected is increasingly important for all those with a stake in the payment system, including consumers, regulators, networks, processors, and financial institutions. In an effort to fulfill the Payment Cards Center’s (PCC) goal of developing meaningful insight into consumer payments, this paper expands previous research conducted by the PCC on prepaid cards and one of the largest subsets of prepaid cards, gift cards. ${ }^{13}$ Moreover, this paper focuses on how industry practices and related regulatory actions respond to market innovations, a theme relevant to the PCC’s research. ${ }^{14}$

This paper is divided into "Closed-Loop” and “Open-Loop” sections, and each addresses the state laws, Federal Trade Commission orders, financial regulatory agency guidelines, and payment network

\footnotetext{
${ }^{11}$ See generally the Federal Reserve System’s “2007 Electronic Payments Study,” which documents that electronic payments now account for over two-thirds of all noncash consumer payments).

${ }^{12}$ Estimates of gift-card sales vary widely. Gift-card sales for 2006 are estimated at between $\$ 72.8$ billion to $\$ 80$ billion. See Philip Ewing, "More States Sold on Reforming Gift Cards,” Stateline, (October 17, 2006), p. 1. See also "Avoid Gift Card Pitfalls," ConsumerReports.org (December 2007), p. 1, which cites a TowerGroup estimate. See also Pauline Smale, "CRS Report for Congress: Gift Cards," Congressional Research Services, Library of Congress, Order Code RS22431, (October 5, 2007), p. 2, which cites the Bureau of National Affairs, "Daily Report for Executives,” January 25, 2007, 16, p. EE-2 and estimates 2006 holiday season gift-card sales at \$27 billion. Giftcard sales for the 2007 holiday season, the period between the day after Thanksgiving and New Year's Day, are estimated to be between $\$ 26.3$ billion and \$35 billion. See "Gift Cards More Popular Than Ever, According to NRF," National Retail Federation press release, (November 13, 2007), p. 1; and "Spending on Gift Cards Seen Increasing 25\%,” Bloomberg News, (December 27, 2007), p. 1. Gift-card sales for 2007 are estimated to be \$97 billion. See Nanette Byrnes, “The Scramble for Gift-Card Cash,” Business Week, (January 24, 2008), p. 1.

${ }^{13}$ See, for example, Mark Furletti, "Prepaid Card Markets and Regulation," Federal Reserve Bank of Philadelphia Payment Cards Center Discussion Paper (February 2004); "Prepaid Cards: How Do They Function? How Are They Regulated?” Federal Reserve Bank of Philadelphia Payment Cards Center Conference Summary (June 2004); Mark Furletti and Stephen Smith, "The Laws, Regulations, and Industry Practices That Protect Consumers Who Use Electronic Payment Systems: ACH, E-Checks \& Prepaid Cards,” Federal Reserve Bank of Philadelphia Payment Cards Center Discussion Paper (March 2005); and Julia Cheney, "Prepaid Card Models: A Study in Diversity," Federal Reserve Bank of Philadelphia Payment Cards Center Discussion Paper (March 2005).

${ }^{14}$ See, for example, Mark Furletti, "The Laws, Regulations, and Industry Practices That Protect Consumers Who Use Electronic Payment Systems: Policy Considerations,” Federal Reserve Bank of Philadelphia Payment Cards Center Discussion Paper (October 2005); and Stanley Sienkiewicz, "Prepaid Cards: Vulnerable to Money Laundering?,” Federal Reserve Bank of Philadelphia Payment Cards Center Discussion Paper (February 2007). See also Michele Braun, James McAndrews, William Roberds, and Richard Sullivan, "Understanding Risk Management in Emerging Retail Payments,” Federal Reserve Bank of New York Economic Policy Review (forthcoming 2008).
} 
rules that operate to preserve value loaded by consumers at the time the card is purchased or to return the underlying value to consumers when the card is no longer used or has expired.

\section{Closed-Loop Gift Cards}

Closed-loop gift cards are typically sold by individual retailers, serviced by those retailers (or their agents), and function only at that particular retailer's locations. As noted, closed-loop cards account for both the majority of gift cards sold and the majority of dollars loaded onto gift cards. At present, no federal laws or regulations protect consumers who purchase and use closed-loop gift cards, although the Federal Trade Commission has used its authority to issue two public orders regulating the practices of large retailers that issue closed-loop gift cards. Instead, the vast majority of protections that consumers who use closed-loop gift cards enjoy come from state laws. Two types of state laws form the primary protections for consumers who use closed-loop gift cards: (1) state gift-card laws, which set disclosure and other substantive operation requirements for gift-card programs, and (2) state abandoned property laws and funds reimbursement provisions of gift-card laws, which require unused or forgotten underlying card funds to be turned over to the state or refunded to consumers.

\section{A. State Gift-Card Laws}

Currently, approximately 40 states and the District of Columbia permit closed-loop gift cards’ underlying funds to be reduced in value or extinguished entirely as a result of issuance fees, service fees, dormancy charges for nonuse, or expiration (so long as issuers comply with notification requirements, usability periods, or other legal requirements). ${ }^{15}$ Of these states, the majority have gift-card or gift-

\footnotetext{
15 Alabama, Alaska, Arizona, Arkansas, California (permits only a dormancy fee),Colorado, Delaware, Florida,* Georgia, Hawaii, Idaho, Illinois (only for cards issued before January 1, 2008), Indiana, Iowa, Kansas, Kentucky, Louisiana, Maine (but only a one-time transaction fee, load fees, or charges for failure to claim property within a specified period), Maryland, Massachusetts, Michigan, Mississippi, Missouri, Nebraska, Nevada, New Hampshire (only gift cards with face values above \$100 may expire), New Jersey, New Mexico, New York, North Carolina, North Dakota, Ohio, Oklahoma, Oregon (permits gift cards to expire but only when expiration is disclosed on the card face in 10-point type, the card is sold below face value, and the card does not expire until 30 days after sale), Pennsylvania, South Carolina, South Dakota, Tennessee, Texas, Utah, Vermont, West Virginia, Wisconsin, and Wyoming. California permits only a dormancy fee. *Note that Florida is included here because it technically permits some closed-loop gift cards to expire, including cards distributed as part of a conference or as an employee
} 
certificate statutes that regulate practices permitted in closed-loop gift-card programs. ${ }^{16}$ Typically, these statutes offer protections for those who use closed-loop gift-card products via specific rules that regulate what fees closed-loop gift-card issuers ${ }^{17}$ or program operators may charge, the length of time before cards may expire, the practices permitted before underlying funds are abandoned, and disclosures that must be made to consumers. ${ }^{18}$ However, these protections vary widely. For example, provisions stipulating the amount of time that must pass before cards may expire range from those that permit expiration within the first year to those that require a minimum of seven years before expiration. ${ }^{19}$ In addition to setting time periods for gift-card acceptance, state gift-card statutes generally establish baseline notification requirements that must be met before fees can be charged or cards can expire. For example, most state gift-card statutes require essential program terms to be printed on the faces of all gift cards, placed on the cards with a sticker, or included in a separate writing that accompanies the sale of the cards. ${ }^{20}$ Gift-card program operators who fail to make mandated disclosures are generally prohibited from charging fees or terminating their redemption obligations via expiration dates and may, as a result of their failure to disclose terms, be subject to fines or be required to submit a greater portion of remaining funds under state abandoned property laws. ${ }^{21}$ Additionally, program operators may potentially face class action lawsuits.

incentive. Florida gift-card laws, however, are generally more restrictive and do not permit fees or expiration. See Fla. Stat. § 501.95 et seq. (2007).

${ }^{16}$ A compilation of state groupings and references to state statutes is on file with the author. These groupings are current through March-May 2008. A publicly available list of state gift-card statutes is available at the National Conference of State Legislatures’ website: http://www.ncsl.org/programs/banking/GiftCardsandCerts.htm.

${ }^{17}$ As used in this section, the term "issuer" refers to nonfinancial institution issuers or closed-loop gift cards.

${ }^{18}$ See the figure on State Gift Card Statute Status, p. 8.

${ }^{19}$ Compare, for example, Iowa Code $\S 556.9$, which allows dormancy charges and fees to begin soon after the sale so long as contract and notification requirements are met, for example, Mass. Gen. Laws ch. 266 § 75C, which requires a seven-year redemption period before a gift card can expire.

${ }^{20}$ See, for example, Tex. Bus. \& Com. Code Ann. § 35.42; Ga. Code Ann. § 10-1-393(b)(33)(A) et seq.; and Ariz. Rev. Stat. Ann. §§ 44-7402.

${ }^{21}$ See, for example, Haw. Rev. Stat. § 481B-13, which mandates that gift certificates that do not have their expiration dates clearly printed on them or on the sales receipt accompanying the initial transaction be redeemable “in perpetuity”; and Mass. Gen. Laws ch. 200A § 5D (2007), which imposes mandatory fees if terms are not disclosed and cards are subsequently charged fees or have expired. See also Idaho Code Ann. §§ 14-502 \& 14-514, which requires that gift certificates without their expiration dates prominently displayed on their faces be reverted to the state under abandoned property laws at full face value, rather than at the unused amount; and 765 Ill. Comp. Stat. $\S \S 1025 / 10.6$, which requires that gift cards' underlying and remaining unused funds be turned over to the state 
A few states go beyond imposing disclosure requirements or setting periods before fees can be charged or cards expired and provide greater protections for the value loaded by consumers at the time gift cards are purchased. California, for example, prohibits expiration dates and all fees but dormancy fees. ${ }^{22}$ New Hampshire, on the other hand, permits expiration dates but prohibits all fees. In doing so, New Hampshire law also distinguishes between closed-loop gift cards based on their face value permitting expiration dates only for cards with face values above $\$ 100 .{ }^{23}$ However, while New Hampshire law permits expiration of gift cards above \$100, it requires that all unused funds be turned over to the state upon expiration. Like New Hampshire, Vermont prohibits all fees but permits expiration dates. ${ }^{24}$ Even more protective, Connecticut, Florida, Minnesota, Montana, Rhode Island, and Washington have laws that essentially prohibit expiration dates and disallow reduction of value for dormancy altogether. ${ }^{25}$ Notably, this small group of states appears to be leading a trend toward enacting stronger protections for consumers who use gift cards, particularly closed-loop gift cards. ${ }^{26}$ In Illinois, for example, gift cards sold after January 1, 2008, can no longer be subject to any after-purchase fees and cannot expire within five years from the date of sale. ${ }^{27}$ In Massachusetts, the legislature recently passed a bill imposing a fee-differentiating approach that prohibits some fees and requires notification of others. ${ }^{28}$ Under Massachusetts’ new law, operators of closed-loop gift-card programs that charge “dormancy fees, latency fees, administrative fees, periodic fees, service fees or other fees that have the effect of reducing

under abandoned property laws only if the gift card issued had an expiration date or fees and it was not within the practice of the issuer not to charge those fees or expire their obligation.

${ }^{22}$ Cal. Civil Code $\S 1749.5$ et seq. (2008).

${ }^{23}$ N.H. Rev. Stat. Ann. §§ 358-A:1, 358-A:2, 471-C:2 \& 471-C:16 (2008).

${ }^{24}$ Vt. Stat. Ann tit. 8, ch. $81 \S 2701$ et seq.

${ }^{25}$ See, for example, Conn. Gen. Stat. Ann. §§ 3-5(a), 3-65c, 3-73(a) \& 42-460 (2007); Fla. Stat. § 501.95 et seq. (2007), which permits expiration on a few enumerated closed-loop gift cards (for example, employee incentive program cards and cards transferred as part of convention, conference, or vacation packages); Minn. Stat. ch. 325G $\S 53$ (2007); Mont. Code Ann. §§ 30-14-108 \& 30-14-102 (2007); R.I. Gen. Laws §§ 6-13-12 \& 33-21.1-14 (2006); and Wash. Rev. Code $\S \S 19.240 .010,19.240 .020(1)(a), 19.240 .030$ \& 19.240.040 (2008), which prohibits expiration but permits dormancy fees or inactivity charges once every 24 months at a rate of $\$ 1$ per month only on cards with a value of $\$ 5$ or less.

${ }^{26}$ See Philip Ewing, “More States Sold on Reforming Gift Cards,” Stateline.org, (October 17, 2006), p. 1, which details an increase in awareness among state legislatures of the protections available to consumers who use gift cards.

${ }^{27} 815$ Ill. Comp. Stat. § 505/2SS(b) (2007).

${ }^{28}$ Massachusetts Sen. 2345, $185^{\text {th }}$ Gen. Assembly, Reg. Sess. (September 27, 2007), signed into law and enacted on March 11, 2008, as Chapter 58 of the Acts of 2008. 
the total amount for which the holder may redeem” a card face a maximum fine of $\$ 300$ per incident. ${ }^{29}$ However, "purchase fees, activation fees, renewal fees or cancellation fees,” while generally allowed, must be disclosed "in writing on the package" or on the gift card. ${ }^{30}$ Failure to do so results in a $\$ 300$ fine per incident. While more protective gift-card legislation has recently been enacted in Illinois and Massachusetts, many other state legislatures are in the process of debating similar laws. In Michigan, for example, both the House of Representatives and the Senate have drafted legislation prohibiting fees from being charged or cards from expiring within five years and calling for all gift cards that expire to have their expiration dates printed on the face of the card. ${ }^{31}$ In Delaware, the House of Representatives has proposed prohibiting expiration dates for all closed-loop gift cards sold within state borders. ${ }^{32}$ In Wisconsin, the legislature has proposed both prohibiting expiration dates and fees on gift cards and requiring conspicuous disclosure of gift-card terms and conditions. ${ }^{33}$

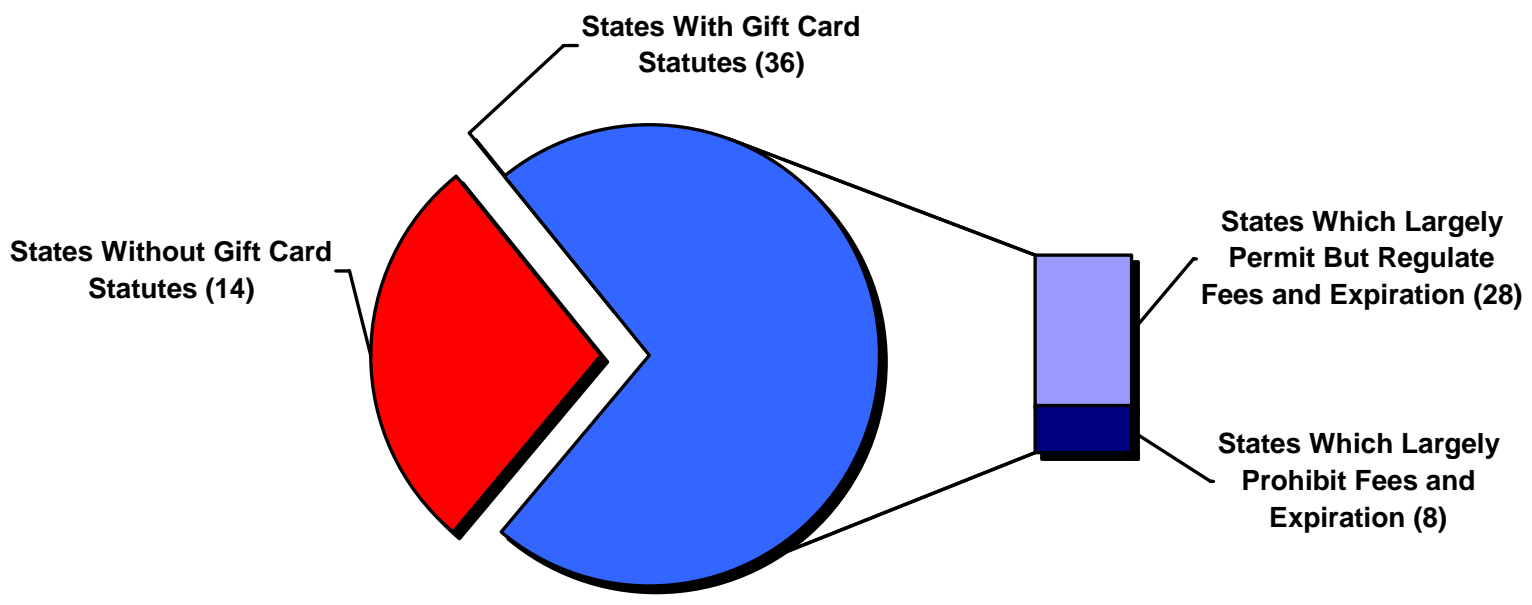

Figure. State Gift-Card Statute Status

${ }^{29}$ Id.

${ }^{30}$ Id.

${ }^{31}$ Michigan, S. 387, $94^{\text {th }}$ Gen. Assembly, Reg. Sess. (June 13, 2007); Michigan, H. 4317 \& 4680, $94^{\text {th }}$ Gen. Assembly, Reg. Sess. (November 28, 2007). See Michigan H. Bills number 4317, 4050 \& 4680 and Michigan S. Bills number 274, 387 \& 388 (for 2008 legislative initiatives concerning gift cards).

${ }^{32}$ Delaware H. 52, $144^{\text {th }}$ Gen. Assembly, Reg. Sess. (February 27, 2007).

${ }^{33}$ Wisconsin Sen. 191, 2007-2008 Gen. Assembly, Reg. Sess. (May 21, 2007); Wisconsin Assembly 360, $2007-$ 2008 Gen. Assembly, Reg. Sess. (May 29, 2007); Wisconsin Sen. 245, 2007-2008 Gen. Assembly, Reg. Sess. (July 25, 2007); and Wisconsin Assembly 471, 2007-2008 Gen. Assembly, Reg. Sess. (July 26, 2007). See also Wisconsin Assembly Bill 583, and Senate Bills 292 and 392 (the 2008 iterations of proposed legislation). 


\section{B. State Abandoned Property Laws and Fund Reimbursement Provisions}

With annual unused underlying gift-card funds estimated to be in the multi-billion dollar range and major retailers like Best Buy and Home Depot claiming, respectively, \$43 million and \$24 million of unspent funds associated with their closed-loop gift cards as 2007 income, ${ }^{34}$ state authorities have begun agitating for the application of state abandoned property laws to closed-loop gift-card programs. ${ }^{35}$ In fact, the laws in approximately 20 states specifically ${ }^{36}$ require unclaimed funds accessible by one or all types of closed-loop gift cards to be reported and reverted to the state in accordance with abandoned property laws. ${ }^{37}$ Among these states there are two fundamental groups: (1) those that require partial reversion of remaining unclaimed underlying funds ${ }^{38}$ (common among this group is a reversion requirement of 60 percent of funds remaining, particularly if the gift card is redeemable for merchandise only), and (2) those that require the reversion of all ${ }^{39}$ unused funds. ${ }^{40}$ Notably, several states within these groupings require that only funds underlying cards with expiration dates or fees be turned over. ${ }^{41}$ Generally, when applied to gift-card programs, these laws operate on the presumption that unclaimed underlying funds associated with cards that have had no activity attributable to the card owner for a fixed amount of time are

\footnotetext{
${ }^{34}$ See Brian Rogal, "Prepaid’s Breakage Windfall,” Cards \& Payments, Prepaid Trends, (April 2007), p. 18, which cites a TowerGroup estimate for annual unused underlying gift-card funds and which notes Best Buy and Home Depot breakage.

${ }^{35}$ See Pat Wellenbach, "Maine Looks to Profit From Unused Gift Cards,” Associated Press, December 21, 2007, p. 1; and Jerry Harkavy, “Maine Lays Claim to Consumers’ Unused Gift Cards,” SmartMoney, December 20, 2007, p. 2.

${ }^{36}$ Either (1) by including gift cards within enumerated lists of property subject to abandoned property law requirements, or (2) by defining "gift certificates" so as to include gift cards while making gift certificates subject to abandonment and reporting requirements. The states are Alaska, Colorado, Delaware, Hawaii, Illinois, Iowa, Louisiana, Maine, Montana, Nebraska, Nevada, New Hampshire, Mew Mexico, New York, North Carolina, Pennsylvania, Tennessee, Texas, Virginia, Washington.

${ }^{37}$ A compilation of references to state abandoned property statutes is on file with the author.

${ }^{38}$ Including Maine, Montana (requires 60 percent of abandoned funds be remitted to the state for gift cards redeemable for merchandise only and only when the issuer sold more than \$200,000 in gift cards in the prior fiscal year), Nevada, New Mexico (if redeemable in merchandise only), and North Carolina (but only when the card has an expiration date), for example.

${ }^{39}$ Many state abandoned property laws require escheat of the entire "face value" of an unused payment instrument. Because, in the case of gift cards, a literal reading of these requirements would result in program operators being required to escheat more than the actual value accessible via the card, industry analysts have raised the issue of whether these statutes, written largely for gift certificates, can be fairly applied to gift cards that function differently than gift certificates.

${ }^{40}$ Including Illinois (only if issued before 2003-2004 or if an expiration date or fees apply), Nebraska (but only if fees or expiration apply), New Hampshire, Texas, Pennsylvania (but only when expiration dates or fees are imposed), and Washington (imposes requirements similar to Pennsylvania's), for example.

${ }^{41}$ Including Connecticut, Illinois, North Carolina, Pennsylvania, and Washington, for example.
} 
abandoned, and hence the funds, or a portion thereof, must be turned over to that state. Assuming custody over the property, states either return the property to the original purchaser or owner of the gift card ${ }^{42}$ or use the funds for the benefit of the general public. ${ }^{43}$

While state abandoned property laws may protect consumer interests by creating a system for the return of unused funds to the consumer, few closed-loop gift-card vendors solicit consumer identification information at the time of sale, making this a difficult protection for consumers to realize. ${ }^{44}$ In an attempt to create a simpler and more effective process for consumers to recover unspent value on closed-loop gift cards, several states have begun enacting legislation that requires a cash refund to consumers at the point of sale when their gift-card balances drop below particular threshold amounts. ${ }^{45}$ Called funds reimbursement provisions, ${ }^{46}$ these laws typically remove the state from the process of returning unused underlying funds. Instead, they require that consumers be offered cash back, or the option of receiving cash back, when they present their gift cards at the point of sale and the transaction for which the card is used causes the underlying funds balance to fall below a certain amount. California, for example, recently enacted an amendment to its gift-card laws that stipulates that when a consumer presents his or her closed-loop gift card to conduct a transaction and the remaining balance is $\$ 10$ or less, or falls below this threshold as a result of the purchases made, the consumer must be given cash back upon request. ${ }^{47}$

\footnotetext{
${ }^{42}$ This is the approach outlined in the Uniform Unclaimed Property Act, a model statute created by the National Conference of Commissioners for Uniform State Laws for enactment by states.

${ }^{43}$ Compare, for example, N.H. Rev. Stat. Ann. § 471-C:16 (1997), which mandates that gift-card funds reverted to the state shall "remain in the custody of the state unless and until returned to the owner," with N.Y. Aband. Prop § 102 (Consol. 2007), which declares it the policy of the state of New York to use abandoned gift certificate funds for the benefit "of all the people of the state."

${ }^{44}$ See Scott Thurm and Pui-Wing Tam, "States Scooping Up Assets From Millions of Americans - 'Unclaimed Property’ Fattens Public Coffers,” Wall Street Journal, (February 4, 2008), p. 1, which discusses this phenomenon generally.

${ }^{45}$ Including, for example, California and Vermont.

${ }^{46}$ See, for example, Deborah Thoren-Peden, Anna M. Graves, Daveed A. Schwartz, Erin F. Fonte, and Catherine Schneider, "New California Gift Card Amendment Requires Cash Back on Request for Balances Under \$10," Pillsbury, Winthrop, Shaw \& Pittman LLP Client Alert (December 20, 2007).

${ }^{47}$ Signed into law October 13, 2007, California Senate Bill 250 modifies $\S 1749.5$ of the California Civil Code by adding subsection (b)(2), which reads, "Notwithstanding paragraph (1), any gift certificate with a cash value of less than ten dollars (\$10) is redeemable in cash for its cash value.” While the language of this subsection is similar to that of subsection (b)(1), legal analysts see the addition of this section as a manifestation of legislative intent to mandate that consumers be refunded cash at the completion of a transaction. However, unlike some cash refund
} 
Vermont gift-card statutes have two similar provisions. The first requires that "[f]ollowing the expiration date of the gift certificate, the unused portion of the gift certificate shall be returned to the holder of the gift certificate, if requested [by the consumer]." ${ }^{48}$ The second states that "[i]f the remaining value of a gift certificate is less than $\$ 1.00$, the gift certificate shall be redeemable in cash for its remaining value upon the demand of the holder of the gift certificate.” 49 Vermont law includes gift cards within its definition of gift certificate. ${ }^{50}$ Like those portions of California and Vermont law that require consumers be given the option to have the remaining underlying funds returned, a recently enacted amendment to Massachusetts' gift-card law requires that "purchaser[s] or holder[s] of a gift certificate...shall make an election to receive the balance in cash or continue using the gift certificate.”51 The statute, which applies to closedloop cards or cards usable at single and affiliated retailers, creates different rules for different types of closed-loop cards. If the particular gift card is not reloadable, the option must be offered when the card reaches 10 percent of its face value. If the card is reloadable, the choice must be offered to the consumer when the balance reaches $\$ 5$.

Similar provisions concerning funds reimbursement are currently being introduced in Illinois, Minnesota, and Washington. ${ }^{52}$ If enacted, Illinois House Bill 4719 would amend the state’s Consumer Fraud and Deceptive Business Practices Act to read: “The holder of a gift certificate issued on or after January 1, 2009 that has a balance of less than $\$ 10$ must be given the option of receiving that balance in cash." ${ }^{53}$ Like California, Illinois would pick \$10 as the threshold amount.

\footnotetext{
laws, California's law is not limited to presenting cards at the point of sale and may, arguably, cover online purchases as well.

${ }^{48}$ Vt. Stat. Ann tit. 8, ch. $81 \S 2702$ (2008).

${ }^{49}$ Id. at $\S 2704$.

${ }^{50}$ Id. at $\S 2701$.

${ }^{51}$ Massachusetts Sen. 2345, $185^{\text {th }}$ Gen. Assembly, Reg. Sess. (September 27, 2007), signed into law and enacted on March 11, 2008 as Chapter 58 of the Acts of 2008, at §§ 1 \& 2.

${ }^{52}$ See Frederick H. Lowe, "Illinois Bill Would Reimburse Funds Unspent on Gift Cards,” ATM \& Debit News, March 13, 2008, p. 3.

${ }^{53}$ Illinois H. 4719, $95^{\text {th }}$ Gen. Assembly, Reg. Sess. (January 30, 2008).
} 


\section{Federal Trade Commission Decisions}

In two recent public decisions, the Federal Trade Commission (FTC) exercised powers granted to it under the Federal Trade Commission Act $^{54}$ to protect consumers who use closed-loop gift cards. ${ }^{55}$ Essentially, the FTC concluded that making positive representations about the long-term usability of cards while failing to adequately disclose fees charged in connection with the operation of closed-loop gift-card programs, particularly dormancy fees that reduce underlying card value, is an unfair and deceptive practice. In other words, the FTC found that consumers were wrongly misled by the assertion at the point of sale that cards are redeemable in perpetuity for their full values when undisclosed fees decreased cards’ underlying stored values almost immediately.

In In re Darden Restaurants, Inc., the FTC found that Darden Restaurants, Inc., GMRI, Inc., and Darden GC Corp. (Darden), the collective sellers and operators of the Darden gift-card program, had failed to adequately disclose fees charged for dormancy and that this failure, in conjunction with Darden's representation that its gift cards could be redeemed for their full value, amounted to a deceptive practice. ${ }^{56}$ Darden, prior to the order, had been in the practice of selling gift cards in its restaurants (Olive Garden, Red Lobster, Smokey Bones, and Bahama Breeze), online, and through third parties. Sold in denominations between $\$ 5$ and $\$ 250$, Darden charged a \$1.50 dormancy fee every month beyond the fifth month of nonuse for cards sold before November 2004, and beyond the $24^{\text {th }}$ month for cards sold after November 2004. ${ }^{57}$ In some cases the charging of fees depleted the entire remaining value, rendering the card worthless or expired. The FTC further found that Darden had failed to disclose these fees entirely and that disclosures that were made were inadequate. ${ }^{58}$ Fees physically disclosed on cards were printed in a five-point font but were, at times, “obscured by miscellaneous other information” or by the design of the

\footnotetext{
${ }^{54}$ See 15 U.S.C. § 41 et seq., and § 45 Unfair methods of competition unlawful; Prevention by Commission (2008)

${ }^{55}$ See In re Darden Restaurants, Inc., et al., Decision and Order of the FTC, Docket No. C-4189 (May 7, 2007); and In re Kmart Corp. et al., Decision and Order of the FTC, Docket No. C-4197 (August 14, 2007).

${ }^{56}$ In re Darden Restaurants, Inc., et al., Complaint of the FTC, at 3, Docket No. C-4189 (May 7, 2007).

${ }^{57}$ Id., p. 2.

${ }^{58}$ Id.
} 
card's graphics. ${ }^{59}$ The FTC noted that marketing materials and gift-card order forms issued by Darden had 'fail[ed] to direct consumers' attention to the dormancy fee disclosure on the back of their gift cards or [to] otherwise notify[] consumers of the dormancy fee.” ${ }^{\prime 0}$ The FTC ultimately concluded that this failure, in connection with the manner in which the Darden gift card was marketed, amounted to a false and misleading representation that cards could be redeemed for their full value in perpetuity. ${ }^{61}$

As a result of its finding, the FTC ordered Darden to engage in both ameliorative and systematic actions. ${ }^{62}$ The FTC ordered Darden to: (1) “clearly and prominently” divulge fees in advertising and at the point of sale; (2) disclose fees on the front of all gift cards sold; (3) refrain from collecting fees on any gift card sold before the date of the order; (4) restore all fees assessed on any gift card before the order was put into place; (5) notify consumers that fees are being restored; and (6) maintain, distribute, and file reports demonstrating compliance with the order. ${ }^{63}$

In In re Kmart Corp., the FTC analyzed a second closed-loop gift-card program for unfair trade practices, a program operated by Kmart and its subsidiaries. ${ }^{64}$ After examining Kmart’s gift-card program, the FTC made the determination that Kmart had represented to consumers that its gift cards were redeemable for the full face value, noting that "[i]n some instances [Kmart] sells the Kmart Gift Card affixed to cardstock that states the consumer can 'use [the card] like cash at all Kmart locations.”,65 The FTC drew attention to statements made on Kmart's website that cards "never expire.” ${ }^{66}$ However, despite any such express or implied affirmations made by Kmart, a \$2.10 per month dormancy fee was charged after 24 consecutive months of nonuse. ${ }^{67}$ Because the fee was charged retroactively, cards that went unused for 24 consecutive months were charged \$50.40 in inactivity fees (\$2.10 for each month in the 24-month period). The FTC found that this practice effectively rendered many cards valueless or

\footnotetext{
${ }^{59}$ Id.

${ }^{60}$ Id., pp. 2-3.

${ }^{61}$ Id., p. 3.

${ }^{62}$ In re Darden Restaurants, Inc., et al., Decision and Order of the FTC, Docket No. C-4189 (May 7, 2007).

63 Id., pp. 4-7.

${ }^{64}$ In re Kmart Corp. et al., Decision and Order of the FTC, Docket No. C-4197 (Aug. 14, 2007).

${ }^{65}$ In re Kmart Corp. et al., Complaint of the FTC, at 2, Docket No. C-4197 (Aug. 14, 2007).

${ }^{66}$ Id., p. 3.

${ }^{67}$ Id., p. 2.
} 
expired, since the size of the dormancy fee often equaled the remaining value accessible via the card. ${ }^{68}$ The FTC further found that fees and charges were not disclosed or were not disclosed adequately, noting that fees were frequently printed in a five-point font on the back of the cards, were obscured from view by packaging, were often not understandable, or were disclosed in confusing syntax. ${ }^{69}$

Finding that Kmart's practices constituted an unfair or deceptive act or practice, the FTC, as it had in the Darden case, ordered Kmart to make ameliorative and systematic changes. These changes, substantially similar to those required of Darden, include: (1) "clearly and prominently” divulging fees in advertising and at the point of sale; (2) disclosing fees on the front of all gift cards sold; (3) refraining from collecting fees on any gift card sold before the date of the order; and (4) maintaining, distributing, and filing reports which demonstrate compliance with the order ${ }^{70}$ However, unlike Darden, Kmart was not ordered to institute an automatic and retroactive refund of fees levied on cards. ${ }^{71}$ Instead, Kmart was ordered to create and distribute to all retail locations a written refund policy, to notify consumers that they were entitled to a refund of assessed fees, and to provide a physical means for requesting a refund, including a telephone number, e-mail address, and street address where consumers could request a refund. $^{72}$

While consumers cannot individually avail themselves of protections under the Federal Trade Commission Act, the FTC’s rulings, in effect, begin to set default best practices for disclosure requirements in closed-loop gift-card programs. Moreover, by openly deterring closed-loop gift card issuers from failing to disclose fees or from characterizing fees in confusing ways, the FTC provides protection for consumers who use gift cards.

\footnotetext{
${ }^{68}$ Id.

${ }^{69}$ Id.

${ }^{70}$ Kmart, Decision and Order of the FTC, pp. 4-8.

${ }^{71}$ The decision not to order a re-crediting similar to what was ordered in Darden is the subject of a dissent filed by the commissioners; see In re Kmart Corp. et al., Statement of Commissioners Pamela Jones Harbour and Jon Leibowitz, File No. 062-3088.

${ }^{72}$ Kmart, Decision and Order of the FTC, pp. 4-5.
} 


\section{Retailer Practices}

Consumers largely bear responsibility for loss or theft of their closed-loop gift cards. However, in 2002, New York state’s then attorney general, Eliot Spitzer, began investigating large retailers concerning their policies about lost or stolen closed-loop gift cards for which consumers possessed card-identifying purchase information. ${ }^{73}$ After probing retailers’ practices and policies, which largely made consumers responsible for lost or stolen cards, Attorney General Spitzer reached an agreement with Home Depot to change its national policy concerning lost or stolen cards that could be identified by the purchasing consumer. Under the agreement, Home Depot established a new rule that permits consumers whose gift cards have been lost or stolen to have them deactivated and replaced so long as they can provide some sort of proof of purchase. Soon after the attorney general reached the agreement with Home Depot, other large national retailers established similar policies, including Best Buy, Bloomingdale’s, Borders, Circuit City, CompUSA, Disney Stores, Eckerd, J.C. Penny, Kohl’s, Macy’s Musicland, Nordstrom, Sears, Roebuck \& Co., Target, The Sports Authority, Inc., Toys R Us, Inc., and Walden Books. ${ }^{74}$ Typically, under the rules of these programs, a customer seeking to establish proof of purchase must produce either a sales receipt, a transaction record (for example, a statement from a credit card issuer connected to a credit card used to purchase a gift card), or a cancelled check. Although consumers still largely bear responsibility for loss or theft of their closed-loop gift cards, these agreements create a de facto standard among the nation's largest retailers to protect against these risks for those cards for which consumers possess identifying information.

\section{E. Summary $^{75}$}

Although protections for consumers who use closed-loop gift cards are derived from a number of sources, including state gift-card laws, state abandoned property laws, fund reimbursement provisions of state law, Federal Trade Commission enforcement actions, and retailer practices, there is some

\footnotetext{
73 "Home Depot Reforms Gift Card Policy, Consumers Will be Protected Against Lost or Stolen Cards," Office of the New York State Attorney General press release (July 27, 2002).

74 "National Retailers Agree to Improve Gift Card Policies, Spitzer Obtains Commitments to Protect Consumers," Office of the New York State Attorney General press release (February 25, 2003).

${ }^{75}$ See also Appendix A: A Summary of Consumer Protections for Users of Closed-Loop Gift Cards.
} 
consistency among regulatory effects. Essentially, these regulations protect value loaded by consumers at the time of purchase by limiting the fees charged and the expiration practices permitted. While new challenges to consumer protection will certainly arise, such as what consumers ought to do with closedloop gift cards redeemable at bankrupt retailers, ${ }^{76}$ existing regulations ${ }^{77}$ and industry solutions ${ }^{78}$ can lessen the impact of these challenges on consumers.

\section{Open-Loop Gift Cards}

As noted earlier, open-loop gift cards are typically issued by financial institutions, operate over debit or credit card networks, carry a network logo (for example, the NYCE, Cirrus, STAR, Visa, American Express, or MasterCard logos), and can be used at a wider array of retail locations than closedloop cards. Open-loop gift cards generally function wherever a merchant accepts the network with which they are branded. Some open-loop cards are reloadable; that is, consumers can add value to them after a purchase or withdrawal depletes the original stored value. And some open-loop cards, such as the ATM gift card from GiftCards.com, can be used to obtain cash from ATMs or redeemed for cash at merchant locations. ${ }^{79}$ Estimates show that, at present, open-loop gift cards, which account for approximately \$3 billion in annual value loaded, are, on average, loaded with fewer dollars than closed-loop cards in aggregate. ${ }^{80}$ Examples of open-loop gift cards issued by financial institutions include the MetaBank STAR gift card, ${ }^{81}$ National City Visa gift card, ${ }^{82}$ the American Express gift card, ${ }^{83}$ and the KeyBank Key

\footnotetext{
${ }^{76}$ See K. Richard Foster, “Sharper Image Bankruptcy: Ramification for the Gift Card Industry,” paybeforeupdate, 2:7 (April 2008), pp. 4-6; and Cotten Timberlake, "Gift Card Holders May Get Short-Changed by Bankrupt U.S. Stores,” Bloomberg News (May 22, 2008), pp. 1-2, which discusses the impact of bankrupt retailers on the gift-card industry and consumers who hold gift cards.

${ }^{77}$ See, for example, Cal. Civil Code § 1749.6(b) (2008), which requires bankrupt gift-card issuers to honor all gift cards issued prior to the date on which they filed for bankruptcy.

${ }^{78}$ See Sharper Image’s Gift Card Policy in Bankruptcy, available at: www.sharperimage.com/us/en/cust_help /cserv_giftservices_giftcertificates.jhtml and www.kccllc.net/sharperimage (accessed May 28, 2008).

${ }^{79}$ See www.giftcards.com/consumer/atm.html.

${ }^{80}$ See Mercator Advisory Group, "Load on All Cash Access Segments for Network Branded Prepaid, Open Gift Card Segment,” 2007.

${ }^{81}$ See www.itsagiftcard.com/faq.htm; and www.firstdata.com/product_solutions/ prepaid_solutions/pdf/3097_FD_Star_Gift_Card.pdf.

${ }_{82}$ See www.nationalcity.com/personal-banking/products-services/everyday-banking/pre-paid-cards/pages/nationalcity-visa-gift-card.asp?WT.vanity=GiftCard; and http://usa.visa.com/personal/cards/prepaid
} 
Possibilities MasterCard gift card. ${ }^{84}$ When sold by retailers who have business relationships with nationally chartered financial institutions, open-loop cards take the form of, for example, the Simon Mall gift card. ${ }^{85}$ As mentioned earlier, mixed-model products, including "semi-closed” or "semi-open-loop” gift cards, are treated as open-loop products for the purposes of this paper.

The primary protections for consumers who use open-loop gift cards are derived from two sources: (1) federal financial institution regulatory agency guidelines, which set disclosure and other substantive principles for operating gift-card programs, and (2) payment network rules, which provide a number of assorted consumer protections. ${ }^{86}$ In addition to these two sources, provisions of state laws and Federal Trade Commission actions (detailed in the last section) may protect consumers who use openloop gift cards. However, the applicability of state laws to open-loop card programs issued by or through federally chartered financial institutions is evolving as a result of several recent legal decisions that consider state laws in light of preemption and the adjudicative process generally. The term preemption generally refers to the displacement of inconsistent state laws by federal laws under powers granted by the Supremacy Clause of the United States Constitution. Preemption can occur in two ways: through express preemption, whereby congressional statements explicitly indicate that state laws on a particular topic should be precluded by federal law, or through implied preemption. With respect to state laws’ governance of open-loop gift cards issued by federal financial institutions, there are bodies of federal law under which state gift-card laws may be set aside in favor of federal financial regulatory agency guidelines. This is covered in subsection C.

\footnotetext{
/visa_gift_card.html.

${ }^{83}$ See www10.americanexpress.com/sif/cda/page/0,1641,22224,00.asp?us_nu=leftnav.

${ }^{84}$ See www.key.com/html/H-8.html; www.key.com/html/H-8.1.html; and www.mastercard.com/us/personal/en/aboutourcards/gift_prepaid/index.html.

${ }^{85}$ See www.simon.com/giftcard/; and SPGGC, LLC v. Ayotte, 443 F. Supp. 2d 197, 203 (D.N.H. 2006).

${ }^{86}$ While these two sources of protection are considered predominant sources for the purposes of this section, Federal Trade Commission rulings that hold particular gift-card program practices unfair and/or deceptive (covered in the last section of this paper) and certain provisions of state law may also provide protection to consumers who use open-loop gift cards.
} 


\section{A. Federal Agency Guidelines}

Both the Office of the Comptroller of the Currency (OCC) and the Office of Thrift Supervision

(OTS) have issued guidelines intended to direct open-loop gift-card programs run by the financial

institutions they oversee. ${ }^{87}$ While the Federal Reserve and the National Credit Union Administration

(NCUA) have issued no similar pronouncements, the NCUA has stated that, in certain instances, credit

unions may engage credit union service organizations for the purpose of structuring service agreements

with third parties to provide services associated with the creation and operation of gift-card programs and that these services may be made available to credit unions' retail members. ${ }^{88}$ This section focuses first on those consumer protections contained within guidelines issued by the OCC and then on those contained in guidelines issued by the OTS.

The OCC specifically authorizes national banks to operate open-loop gift-card programs and to issue cards. ${ }^{89}$ When national banks do so, the OCC permits them and their agents to charge fees. ${ }^{90}$ However, to protect consumers who buy and use open-loop gift cards, the OCC “expects to see”: (1) expiration dates; (2) "the amount or the existence of any monthly maintenance, dormancy, usage or similar fees;" and (3) a method for obtaining additional information disclosed on the gift card or affixed to the gift card with a sticker. ${ }^{91}$ Additionally, the OCC expects issuers and sellers to make disclosures in

\footnotetext{
${ }^{87}$ See generally OCC Bulletin No. 96-48, 8 (September 1996); OCC publication 98-31, “Guidance on Electronic Financial Services and Consumer Compliance” (July 30, 1998), pp. 10-12; OCC Bulletin No. 2006-34 (August 14, 2006); Amicus Curiae Brief of the Comptroller of the Currency, Julie L. Williams, Chief Counsel, et al., SPGGC v. Ayotte, 488 F.3d 525 ( $1^{\text {st }}$ Cir. 2007); Amicus Curiae Brief of the Comptroller of the Currency, Julie L. Williams, Chief Counsel, SPGGC v. Blumenthal, 505 F.3d 183 ( $2^{\text {nd }}$ Cir. 2007); and corresponding code: 12 C.F.R. $\S \S$ 7.4002(a) (2001), 7.4006 (2001), 7.4009(b) (2004) \& 7.5002(a)(3) (2002). See also OTS Opinion Letter No. P-20048, 10 (October 25, 2004); OTS Opinion Letter No. P-2006-3, 3 (June 9, 2006); OTS, “Guidance on Gift Card Programs" (February 28, 2007), and corresponding code: Sections 4(a) and 5(a) of the Home Owners' Loan Act; 12 U.S.C. § 1462a(b)(2); 12 U.S.C. § 1463(a)(1); 12 U.S.C. § 1464(a)(1); 12 U.S.C. § 1464(b)(1)(A) (2002) \& 12 C.F.R. §§ 545.2 (1989), 555.200(a) (1998) \& 557.10 (1997).

${ }^{88}$ See, for example, letter from Sheila A. Albin, Associate General Counsel, National Credit Union Administration, to Bruce O. Jolly, Esq., Venable LLP, February 7, 2005, pp. 1-2.

${ }^{89}$ See 12 C.F.R. § 5002(a)(3) and OCC Bulletin No. 2006-34 (Aug. 14, 2006), which specifically authorizes national banks to issue gift cards.

9012 C.F.R. § 7.4002(a), which permits national banks to charge fees in connection with gift-card programs; 12 U.S.C. § 24 (Seventh) (2002), which authorizes national banks to engage third-party agents to carry out otherwise authorized activities; and “Activities Permissible for a National Bank, Cumulative 2006," OCC Publication (June 2007), pp. 53, 84.

${ }^{91}$ OCC Bulletin No. 2006-34 at 2.
} 
materials accompanying the sale of cards, including: (1) the name of the card-issuing bank; (2) fees not disclosed on the face of the card; (3) the process for obtaining a replacement card; (4) any restrictions on card use that apply; (5) instances in which purchase authorization may be denied; (6) the importance of tracking the remaining card balance; (7) whether the card may be used in transactions exceeding the remaining card value (and, if not, a means of redeeming the remaining value); (8) information on how the dispute resolution process is initiated; and (9) information regarding any existing policies concerning the issuer's ability to revoke or change terms in the gift-card agreement. ${ }^{92}$ The OCC has stated that this second set of disclosure guidelines was designed so that relevant information would "be passed on with the card to the [ultimate] recipient” or user. ${ }^{93}$

In addition to providing guidelines about what disclosures nationally chartered banks (and their card-selling partners) should make, the OCC also recommends that these entities avoid "engaging in marketing or promotional practices that could mislead a reasonable consumer about the terms, conditions, or limitation of the bank gift card product they are offering." 94 Noting that two practices are particularly misleading, the OCC advises issuers to avoid advertising gift cards as having no expiration date when, in fact, fees charged under the program have a similar effect of substantially reducing a card's value and to avoid describing products using terms that suggest they carry federal deposit insurance when they do not. $^{95}$

Similar to OCC guidelines, gift-card program guidance issued by the OTS recommends both disclosure and substantive practices. ${ }^{96}$ For the stated purpose of "ensur[ing] that consumers receive appropriate and pertinent information about gift cards and products,” the OTS advises the issuers it

\footnotetext{
${ }^{92}$ Id., pp. 2-3.

${ }^{93}$ Id., p. 2.

${ }^{94}$ Id., p. 3.

${ }^{95}$ Id. While the federal deposit insurance portion of these recommendations does not refer directly to "pass through" federal deposit insurance, this is believed to be the most uncertain issue with regard to insurance coverage for these products.

${ }_{96}$ While the OTS’s “Guidance on Gift Card Programs,” released February 28, 2007, is meant to apply to open-loop and closed-loop programs alike, the substantive provisions contained therein are raised in this paper with regard to open-loop programs.
} 
oversees to make disclosures similar to those recommended by the OCC ${ }^{97}$ and to disclose: (1) any fraud, error, or merchant dispute policies; (2) any lost or stolen card policies; (3) amounts of any shipping and handling fees; (4) amounts of any service fees; (5) locations where gift cards may be used; (6) a method for checking or tracking the remaining balance; (7) a phone number or website from which additional information may be obtained; (8) any policies that permit cards to be exchanged for cash; and (9) any policies governing card use at an automated teller machine. ${ }^{98}$ Grouping the recommended disclosures into those that should be made in promotional packaging and those that should be made on cards themselves, the OTS suggests that some accompany the card (through the use of printed inserts or sleeves) and that some be printed on cards or placed on cards with stickers. ${ }^{99}$ Like the OCC, the OTS distinguishes between the purposes behind particular types of disclosures, recognizing that certain information is relevant to the purchaser's decision-making process, while other information is essential to the user's decision-making process and should be in a format in which it can be "passed on from the gift card purchaser to the gift card recipient.”100

Also similar to OCC guidelines, OTS guidelines actively direct issuers to implement certain substantive practices when operating their gift-card programs. ${ }^{101}$ The OTS, for example, advises all giftcard issuers it oversees to "utilize plain language, clear and conspicuous font, and bold headings" when making disclosures, and to avoid using "promotional materials that could mislead a reasonable consumer about the terms, conditions, or limitations of the associations.” ${ }^{102}$ Moreover, the OTS recommends that expiration dates be established at a minimum of 12 months from issuance, if not longer. ${ }^{103}$ Additionally, the OTS makes note of other OTS rules and bodies of federal law, recommending that they be considered when savings associations structure their gift-card programs, and suggesting that properly constructed

\footnotetext{
97 See the OTS’s “Guidance on Gift Card Programs,” p. 20.

98 “Guidance on Gift Card Programs,” pp. 1-3.

99 “Guidance on Gift Card Programs,” P. 3.

${ }^{100}$ Compare OCC Bulletin No. 2006-34, p. 2, which distinguishes between the needs of purchasers and recipients with "Guidance on Gift Card Programs," p. 3, which notes differences between types of disclosures.

${ }^{101}$ See "Guidance on Gift Card Programs,” pp. 1-3.

102،Guidance on Gift Card Programs,” pp. 2-3.

103 “Guidance on Gift Card Programs,” p. 1.
} 
programs will satisfy consumer protection requirements beyond disclosure and expiration requirements. $^{104}$

\section{B. Payment Network Rules}

Similar to policies concerning Visa- and MasterCard-branded ${ }^{105}$ credit and debit cards, payment network policies extended to open-loop gift cards can protect consumers from losing all or a portion of the value loaded on the card by shielding consumers from fraudulent card use or erroneous debits of underlying funds. Essentially, two payment network policies protect consumers who use open-loop gift cards: (1) the "zero liability” policy, ${ }^{106}$ and (2) the card issuer’s ability to initiate a chargeback. ${ }^{107}$ Under "zero liability” fraud protection, networks require issuers of network-branded gift cards to re-credit consumers within five business days for any losses suffered as a result of unauthorized transactions. As a result, consumers are protected from losing any portion of the underlying funds of open-loop gift cards that are accessed as a result of unauthorized card use and that decrease the underlying funds. However, as previous Payment Cards Center research has noted, zero liability protections are limited. ${ }^{108}$ This particular protection may be curtailed if a consumer's account is not in good standing or the consumer has reported two or more fraudulent charges in the previous 12-month period. ${ }^{109}$ Additionally, under the policy, issuers are permitted to hold consumers liable "for fraudulent transactions if there is evidence that the fraud resulted from the consumer's 'gross negligence' (Visa) or

\footnotetext{
104،“Guidance on Gift Card Programs,” pp.1-4.

${ }^{105}$ For the purpose of this analysis, I examined two payment networks' (Visa and MasterCard) rules. While this analysis does not, for example, take into account rules promulgated by other networks, such as American Express or Discover, the analysis assumes that these networks have similar policies.

${ }^{106}$ See http://usa.visa.com/personal/cards/prepaid/reloadable_prepaid_card.html, for Visa's general statement concerning the extension of the "zero liability" policy to reloadable prepaid cards and gift cards; and www.mastercard.com/us/personal/en/cardholderservices/zeroliability.html, for MasterCard's statement regarding the extension of "zero liability" to gift cards.

${ }^{107}$ See Mark Furletti and Stephen Smith, "The Laws, Regulations, and Industry Practices That Protect Consumers Who Use Electronic Payment Systems: ACH, E-Checks \& Prepaid Cards,” pp. 16-20, for a fuller discussion of how this policy is applied in the prepaid card (and therefore gift-card) context. See also MasterCard's "2007 Chargeback Guide,” available at: www.mastercard.com/us/wce/PDF/Chargeback_Guide_Nov_2007_no_contact_info.pdf.

${ }^{108}$ See Furletti and Smith, "The Laws, Regulations, and Industry Practices That Protect Consumers Who Use Electronic Payment Systems: ACH, E-Checks \& Prepaid Cards,” pp. 15-16.

${ }^{109}$ See Furletti and Smith, p. 15.
} 
failure to ‘exercise reasonable care’ (MasterCard).” ${ }^{110}$ Moreover, card issuers are permitted to honor this policy for as long as they please. Thus, particular claims may fall outside the policy window implemented by the card issuer and become ineligible for reimbursement. Previous industry research carried out by the Payment Cards Center has also noted that there is wide variation in the industry's implementation of this particular policy. ${ }^{111}$ Some card issuers permit consumers to avail themselves of the policy for as many as 60 days from the date of the statement on which the fraudulent transaction first appears, and some limit this protection to as few as two days (and further require that a portion of the loss be borne by the consumer). ${ }^{112}$

The second network policy that can protect consumers who use open-loop gift cards is the card issuer's ability to initiate a chargeback for problematic purchases. Generally, this policy is derived from a series of agreements between parties to the electronic payment transaction (including the payment networks, card issuers, merchant banks, and merchants). ${ }^{113}$ Ordinarily extending for up to four months, a chargeback may be exerted in order to reverse erroneous, fraudulent, or improper charges. ${ }^{114}$ The right to initiate a chargeback, however, belongs to the card issuer. ${ }^{115}$ Therefore, while this network rule may protect consumers who use open-loop gift cards, it does so only to the extent that a particular cardholder's issuer sees fit. Additionally, card issuers may impose particular requirements to initiate the chargeback process, including requiring consumers to attempt to contact the retailer to resolve the dispute directly, requiring formal charge disputes to be filed in writing (in the event that attempts to resolve the dispute with the merchant were unsuccessful), or requiring consumers to submit evidence substantiating their claims (such as a sales receipt or contract). ${ }^{116}$ With regard to industry practices concerning the right to

\footnotetext{
${ }^{110}$ See Furletti and Smith, p. 15.

111 See Furletti and Smith, pp. 16-17.

112 See Furletti and Smith,.

${ }^{113}$ See Furletti and Smith, p. 16.

${ }^{114}$ See Furletti and Smith, p. 16. See also Furletti and Smith, “The Laws, Regulations, and Industry Practices That Protect Consumers Who Use Electronic Payment Systems: Credit and Debit Cards,” pp. 13-16, which discusses the chargeback process in more detail.

${ }^{115}$ Furletti and Smith, "The Laws, Regulations, and Industry Practices That Protect Consumers Who Use Electronic Payment Systems: Credit and Debit Cards,” p. 14.

${ }^{116}$ See Furletti and Smith, “The Laws, Regulations, and Industry Practices That Protect Consumers Who Use Electronic Payment Systems: Credit and Debit Cards,” p. 14.
} 
initiate a chargeback for gift-card transactions, previous interviews with industry experts conducted by the Payment Cards Center indicate that, like practices concerning “zero liability” policy application, chargeback policies among open-loop gift-card issuers vary widely. ${ }^{117}$ Some issuers indicate that they will “initiate dispute-related chargebacks for prepaid-card customers” (including open-loop gift card customers) just as they would for credit and debit card customers, while others indicate that the type of relationship the cardholder possesses with the issuing institution will affect the overall likelihood of the issuer’s willingness to engage in particular chargeback processes, such as chargeback-related arbitration. $^{118}$

\section{State Laws}

The applicability of state laws (including state gift-card laws, state abandoned property laws, and various other types of state laws) to open-loop gift-card programs promulgated by nationally chartered financial institutions is a rapidly developing area of the law. While some state statutes specifically exempt gift-card products issued by financial institutions from their purveyance, ${ }^{119}$ others specifically target them. ${ }^{120}$ This general issue — whether state gift-card consumer protection laws may be enforced with regard to open-loop programs — was at the heart of several 2004 actions brought by state attorneys general against one particular open-loop gift-card program that operated in multiple states and was promulgated through various federally chartered financial institutions regulated by the OCC or the OTS. ${ }^{121}$ Recent decisions by the United States Courts of Appeals for the First and Second Circuits in

\footnotetext{
${ }^{117}$ See Furletti and Smith, “The Laws, Regulations, and Industry Practices That Protect Consumers Who Use Electronic Payment Systems: ACH, E-Checks \& Prepaid Cards,” pp. 18-19.

${ }^{118}$ See Furletti and Smith, "The Laws, Regulations, and Industry Practices That Protect Consumers Who Use Electronic Payment Systems: Credit and Debit Cards,” p. 18.

${ }^{119}$ See, for example, Fla. Stat. § 501.95(b) (2007), which exempts gift cards issued by nationally chartered financial institutions from restrictions imposed under the state's gift-card statute requirements so long as they may be used a "multiple unaffiliated merchants”; Kan. Stat. Ann. § 50-6,108(f)(1) \& (3) (2006), which excludes bank-issued cards from the definition of "gift card" under the statute; and N.M. Stat. Ann. § 57-12-26(a) (2007), which exempts gift certificates issued by federally chartered banks and savings and loan associations from the definition of "gift certificate" under the statutes (New Mexico laws treat gift cards as "gift certificates").

${ }^{120}$ See, for example, ME. Rev. Stat. Ann. tit. 33 § 1953(G-1) (2005), which specifically subjects prepaid bank cards, including bank-issued open-loop gift cards, to state abandoned property requirements.

${ }^{121}$ See Simon Property Group, Inc.’s 10K SEC filing of March 16, 2005, at Item 3. Legal Proceedings (noting Commonwealth of Massachusetts v. Simon Property Group, Inc.; State of Connecticut v. Simon Property Group,
} 
these cases have helped to determine when state gift-card consumer protection laws may regulate openloop gift-card programs. ${ }^{122}$

In SPGGC, LLC v. Ayotte, the First Circuit Court of Appeals affirmed the New Hampshire District Court's grant of summary judgment preempting New Hampshire gift-card laws in favor of the OCC and OTS guidelines. ${ }^{123}$ Addressing the preemptory scopes of the National Bank Act (NBA) and the Home Owners' Loan Act (HOLA) separately (the federal laws from which the OCC and OTS derive the power to create gift-card guidelines), the First Circuit turned first to the National Bank Act. Making the initial determination that "a national bank has the power to issue stored value cards that carry expiration dates and administrative fees” under the National Bank Act, the court concluded that New Hampshire's Consumer Protection Act (CPA), which contains New Hampshire’s gift-card laws, directly and indirectly interferes with such powers. ${ }^{124}$ The court noted that New Hampshire’s CPA, which prohibits gift cards with a face value of less than $\$ 100$ from being sold with expiration dates or fees, regulates the terms and conditions of gift cards, directly interfering with terms and conditions that U.S. Bank (a business partner of Simon Malls and an issuer of the Simon Mall gift card) had sole control in setting and indirectly interfering with powers granted to U.S. Bank through the regulation of its agent. ${ }^{125}$ The court reasoned that under these circumstances, regulating the agent effectively "regulates the activities of [the] national bank” itself and creates a conflict between federal and state laws. ${ }^{126}$ In arriving at this portion of its decision, the court reiterated that U.S. Bank had "sole control” over setting the "terms and conditions" of the gift cards sold. ${ }^{127}$

Turning next to the Home Owners’ Loan Act, the First Circuit noted that the New Hampshire attorney general had not argued that the OTS's promulgation of rules governing gift-card programs under

L.P. and SPGGC, Inc.; and Kelly A. Ayotte, Attorney General, State of New Hampshire v. Simon Property Groupall filed Nov. 15, 2004).

${ }^{122}$ See SPGGC, LLC v. Ayotte, 488 F.3d 525 (1st Cir. 2007); and SPGGC, LLC v. Blumenthal, 505 F.3d 183 (2d Cir. 2007).

${ }^{123}$ SPGGC, LLC v. Ayotte, pp. 527-30.

${ }^{124}$ SPGGC, LLC v. Ayotte, pp. 531-33.

${ }^{125}$ SPGGC, LLC v. Ayotte, p. 533.

${ }^{126}$ SPGGC, LLC v. Ayotte, p. 533.

${ }^{127}$ SPGGC, LLC v. Ayotte, p. 5. 
the HOLA were "arbitrary, capricious, or manifestly contrary" to the purposes of the act. ${ }^{128}$ Bypassing this issue, however, the court chose to “defer to the OTS's interpretation of the statute” and concluded both that "OTS regulations permit national thrifts to issue stored value giftcards with expiration dates and administrative fees" and that national thrifts may use third-party agents to assist in "the exercise of national thrift powers.” ${ }^{229}$ Looking at the state and federal laws, the court held that there was indeed an “irreconcilable conflict” between the OTS gift-card guidelines and New Hampshire's gift-card laws and that as a result MetaBank (a business partner of Simon Malls and an issuer of the Simon Mall gift card), and Simon Malls acting as MetaBank’s agent, were entitled to preempt conflicting state gift-card laws. ${ }^{130}$ However, before concluding its opinion, the First Circuit qualified and limited its opinion, stating that:

Our holding should not be interpreted as opining on the adequacy of OCC or OTS regulation of giftcard sales by third party agents; we urge those bodies to ensure that these activities are adequately regulated. Nor does our ruling preclude a state from enacting laws that regulate activities of national banks of national thrifts, so long as those laws do not conflict with the powers granted to national banks or national thrifts by the National Bank Act and the HOLA. ${ }^{131}$

Therefore, even though the First Circuit ultimately held that state gift-card consumer protection laws were preempted here, the court acknowledged that there may be instances in which nonconflicting state laws may provide added consumer protections for users of open-loop gift cards beyond those offered by the OCC and OTC guidelines. ${ }^{132}$

Although, under Ayotte, there may be instances in which state statutes that protect consumers who use gift cards are preempted, open-loop gift-card programs in which fees are set by retailers and not by the card-issuing nationally chartered financial institution may still be subject to regulation under state giftcard laws that limit fees. In SPGGC, LLC v. Blumenthal, the Second Circuit Court of Appeals reviewed

\footnotetext{
${ }^{128}$ SPGGC, LLC v. Ayotte, p. 535.

${ }^{129}$ SPGGC, LLC v. Ayotte, pp. 535-36.

${ }^{130}$ SPGGC, LLC v. Ayotte, pp. 535-36.

${ }^{131}$ SPGGC, LLC v. Ayotte, p. 536.

132 On February 19, 2008, the United States Supreme Court denied Attorney General Ayotte's appeal of this matter (Ayotte v. SPGGC, LLC, 128 S. Ct. 1258 (2008)).
} 
the district court's ruling and held that Connecticut's gift-card laws that protect consumers by prohibiting gift-card dormancy fees are not preempted by the National Bank Act when those fees are set by merchant participants in retail gift-card programs and not the card-issuing national bank. ${ }^{133}$ Looking to an amicus curiae brief, or friend of the court brief, filed by the OCC and the Supreme Court's decision in Watters $v$. Wachovia, ${ }^{134}$ the Second Circuit concluded that a nationally chartered bank may conduct its business “through an unaffiliated third-party [or agent] such as [Simon]," ${ }^{135}$ but that state attempts to regulate that agent's conduct will not automatically be eligible for preemption. ${ }^{136}$ Instead, only where a state has attempted regulation of an agent of a nationally chartered bank and such regulation amounts to encroachment on powers granted to the nationally chartered institution will the state's laws become eligible for preemption. ${ }^{137}$

In analyzing the program between Simon Malls and Bank of America, the Second Circuit noted that Simon possessed the authority to establish terms and conditions, bore the costs of administering the program, and collected and retained all fees associated with the cards. ${ }^{138}$ The court held that in instances where a gift-card program’s structure denies a participating nationally chartered gift-card-issuing bank all authority to determine terms and conditions governing the cards, the application of state statutes prohibiting particular charges and fees to the agent who is selling those cards is lawful and does not interfere with the chartered bank’s exercise of its powers under the NBA and OCC regulations. ${ }^{139}$ In arriving at this portion of its decision the court noted that the amicus brief filed by the OCC was similarly reasoned, stating that:

Significantly, the OCC does not view the regulation of SPGGC's [doing business as Simon Malls] collection of fees as an encroachment on BoA's [Bank of America's] power, stating specifically in its amicus brief that "we do not believe that the state restrictions on Simon charging a monthly service fee in connection with the gift cards would burden or

\footnotetext{
133 SPGGC, LLC v. Blumenthal, 505 F.3d 183, 186.

${ }^{134}$ Watters v. Wachovia, 127 S. Ct. 1559 (2007).

135505 F.3d, p. 190.

136505 F.3d, p. 190.

137505 F.3d, pp. 190-91.

${ }^{138} 505$ F.3d, pp. 186-91.

139505 F.3d, p. 191.
} 
interfere with national bank powers to issue stored-value cards as a payment mechanism." 140

The court, however, elected not to dismiss Simon's claim for preemption of Connecticut's ban on giftcard expiration. ${ }^{141}$ The court concluded that "[u]nlike the various administrative and maintenance fees," the enforcement of state gift-card laws prohibiting gift cards from having expiration dates against Simon Malls may effectively prevent Bank of America from using the Visa network, something it is legally entitled to do under banking regulations. ${ }^{142}$ The court reasoned that if expiration dates are necessary under Visa network rules for the prevention of fraud and the maintenance of cards used over the network and state laws prohibit Simon Mall gift cards from having expiration dates, then enforcing state laws against Bank of America’s agent could interfere with Bank of America’s legal rights. To resolve this issue, the court remanded Simon's claim for preemption of state laws prohibiting expiration dates. ${ }^{143}$ As of the publication of this paper, the remanded case has not been reported. Nonetheless, as a result of this decision, state laws can and do protect consumers who use open-loop gift cards so long as extending those laws to a particular program does not burden or interfere with a nationally chartered financial institution's exercise of its authorized powers or otherwise conflict with federal banking regulatory agency rules and guidelines.

While the Ayotte and Blumenthal decisions lay a framework for determining when state gift-card laws may protect consumers who use open-loop gift cards, the applicability of other provisions of state gift-card laws and other types of state laws are generally yet to be determined. For example, the First Circuit noted in Ayotte that its decision was not meant to extend preemption under the National Bank Act to state statutes regulating "how and where gift cards are marketed," leaving open the possibility that states may use such regulations to provide consumers who use open-loop gift cards protections beyond those contained in current OCC or OTS guidelines. ${ }^{144}$ For example, state laws requiring certain kinds of

\footnotetext{
140505 F.3d, p. 190-91.

141505 F.3d, p. 191-92.

${ }^{142} 505$ F.3d , pp. 191-92.

143505 F.3d, p. 197.

144505 F.3d , p. 5.
} 
disclosures or signage might not be preempted. Additionally, a portion of federal code explicitly declares that certain types of state laws are not inconsistent with federal law governing the operation of national banks. ${ }^{145}$ Under this provision of federal law, state contract laws, for example, are generally nonconflicting and go unpreempted. As a result, consumer actions brought under theories of contract law can provide valuable protections to users of open-loop gift cards. ${ }^{146}$

\section{Summary ${ }^{147}$}

Compared with those regulations governing closed-loop gift cards, the laws, guidelines, and payment network rules that protect consumers who use open-loop gift cards are predominantly derived from sources outside of state law. As a result, federal banking agencies, payment networks, and financial institutions play much larger roles in protecting cardholders. And while state laws may, in some instances, protect consumers who use open-loop gift cards, interactions between federal agency guidelines and state laws are being addressed in the ongoing adjudication of open-loop gift-card programs.

Ultimately, the evolution of protections available to consumers who use open-loop gift cards is part of the normal legal process that serves to refine the specific nature of consumer safeguards.

\section{Conclusion}

Unlike users of traditional debit and credit cards, users of prepaid gift cards do not enjoy the same level of protection under federal banking laws. Nevertheless, and despite periodic pleas for such federal regulatory protections, today's gift-card programs by and large provide substantial consumer protections, protections that have evolved as a result of actions taken by state legislatures, state attorneys general, federal agencies, financial institutions, and payment networks. While some people may argue that the web

\footnotetext{
${ }^{145}$ See 12 C.F.R. § 7.4009 (2004).

${ }^{146}$ See generally Doerhoff v. General Growth Properties, Inc., No. 06-04099-CV-C-SOW, slip op. at 5-6 (W.D. Mo. Nov. 6, 2006); Pleasants v. American Express Company, et al., No. 4:06-CV-1516 (CEJ), slip op. at 1 (E.D. Mo. Aug. 17, 2007); Lee v. American Express Travel Related Services, et al., No. C 07-04765 CRB, slip op. at 5-6 (N.D. Cal. Dec. 6, 2007); and Kaufman v. American Express Travel Related Services Company, Inc., No. 07 C 1707, slip op. at 8-9 (N.D. Ill. March 7, 2008), for examples of cases in which consumers have disputed terms of open-loop gift-card contracts.

${ }^{147}$ See also Appendix B: A Summary of Consumer Protections for Users of Open-Loop Gift Cards.
} 
of state laws and the multitude of parties involved in setting consumer protection standards for gift-card users are overly complicated, the fact remains that prepaid gift cards have enjoyed tremendous success. ${ }^{148}$ In fact, it is difficult to find a major retailer, or even a not so major retailer, that does not offer a closedloop gift card. Additionally, issuers of more broadly accepted network-branded open-loop gift cards have actively marketed this product, raising awareness and use of open-loop cards. Moreover, consumer satisfaction — indeed enthusiasm — for gift cards is high, remaining strong during a period of significant growth in the industry. ${ }^{149}$

As discussed in this paper, the seemingly straightforward notion of a gift card continues to evolve as merchants and payment innovators expand the applications inherent in the pay-now, buy-later prepaid gift-card model. In some sense, one might argue that the apparent success of consumer gift-card protections, as evidenced by increasing sales and high consumer satisfaction levels, is thus far due to the limited risks associated with most gift-card purchases. Generally loaded with low dollar amounts that are “spent” at a familiar merchant shortly after purchase or receipt, gift cards have traditionally represented minimal risks to consumers. For those risks that have existed, and do exist, an assortment of public and private solutions has emerged to provide a variety of consumer protections. However, as payments innovation continues, the situation may change. As noted in this paper, circumstances surrounding a relatively straightforward gift card were altered as the sponsors of the Simon Mall gift card expanded acceptance beyond the traditional single merchant common to most closed-loop gift-card programs and chose to issue through a national bank and federal savings association. Moreover, the inherent greater

\footnotetext{
${ }^{148}$ See Philip Ewing, “More States Sold on Reforming Gift Cards,” Stateline (October 17, 2006), p. 1, in which 2006 sales are estimated to be $\$ 72.8$ billion; “Avoid Gift Card Pitfalls,” ConsumerReports.org (December 2007), p.1, which cites a TowerGroup estimate of 2006 gift-card sales of $\$ 80$ billion; Nanette Byrnes, "The Scramble for Gift-Card Cash,” Business Week (January 24, 2008), p. 1, which puts estimates of 2007 gift-card sales at as much as $\$ 97$ billion; and “Avoid Gift Card Pitfalls," p. 1, which cites a TowerGroup projection that 2008 gift-card sales will surpass $\$ 100$ billion.

${ }^{149}$ See "Gift Card Appeal Remains Strong and Continues to Grow," Business Wire (May 20, 2008), p. 1, which discusses a consumer gift-card survey conducted by First Data Corp.; "Holiday Season 2007: Network Branded Gift Card Outlook," a report from the Network Branded Prepaid Card Association, (November 2007), p. 2, which notes that 93 percent of consumers polled were satisfied with their purchase of a network-branded (typically, open-loop) gift card; and "Attitudes and Purchasing Behaviors of Recipients of Network Branded Gift Cards," a report from the Network Branded Prepaid Card Association (May 2008), p. 10, which notes that 95.6 percent of more than 8,000 consumers polled have had a "good experience" with network-branded (typically, open-loop) gift cards.
} 
flexibility associated with network-branded open-loop gift cards, including potential reload capabilities, will likely lead to new consumer protection concerns as these new models expand beyond the low-value, short-lifetime structure of the original gift-card concept. 


\section{Appendix A: A Summary of Consumer Protections for Users of Closed-Loop Gift Cards}

\begin{tabular}{|c|c|}
\hline Product & Closed-loop gift cards \\
\hline $\begin{array}{l}\text { Scope of Protective } \\
\text { Provisions }\end{array}$ & $\begin{array}{l}\text { How is value loaded by a consumer at the time the card is purchased protected } \\
\text { from surprise or rapid reduction (enabling future card use), and how are unused } \\
\text { or expired funds refunded to consumers? }\end{array}$ \\
\hline Federal Laws & $\begin{array}{l}\text { The Federal Trade Commission Act (under which the FTC has acted to curtail } \\
\text { certain practices- see Federal Agency Actions below). }\end{array}$ \\
\hline $\begin{array}{l}\text { Federal Agency } \\
\text { Actions }\end{array}$ & $\begin{array}{l}\text { FTC public decisions and orders declaring it an unfair and deceptive trade } \\
\text { practice for retail closed-loop gift-card issuers to assert that cards do not expire } \\
\text { or that cards retain their value for a substantial period while charging fees that } \\
\text { have the practical effect of reducing underlying stored values and rendering } \\
\text { cards worthless or expired. }\end{array}$ \\
\hline State Laws & $\begin{array}{l}\text { State gift-card laws* and attorney general actions: } \\
\qquad \begin{aligned} 0 & \text { Require disclosure of terms and conditions, including fees and } \\
& \text { expiration. } \\
0 & \text { Establish periods in which cards must be honored. } \\
0 & \text { Prohibit certain fees. } \\
0 & \text { Prohibit expiration. } \\
0 & \text { Stipulate substantive card program operating procedures. }\end{aligned} \\
\text { Funds reimbursement provisions of state-gift card laws: } \\
\text { o Require that consumers be offered the option to recover remaining } \\
\text { funds in the form of cash back upon request. } \\
\text { State abandoned property laws: } \\
\text { o Create a process by which consumers can be refunded unused or } \\
\text { expired underlying gift-card funds. }\end{array}$ \\
\hline
\end{tabular}




\section{Appendix B: A Summary of Consumer Protections for Users of Open-Loop Gift Cards}

\begin{tabular}{|c|c|}
\hline Product & Open-loop gift cards \\
\hline $\begin{array}{l}\text { Scope of } \\
\text { Protective } \\
\text { Provisions }\end{array}$ & $\begin{array}{l}\text { How is value loaded by a consumer at the time the card is purchased protected from } \\
\text { surprise or rapid reduction of underlying funds (affecting future card use), and how are } \\
\text { card users protected from fraud, reporting errors, and merchant disputes? }\end{array}$ \\
\hline $\begin{array}{l}\text { Federal } \\
\text { Agency } \\
\text { Guidelines }\end{array}$ & $\begin{array}{l}\text { OCC guidelines: } \\
\qquad \text { o Recommend particular disclosures and substantive program procedures. } \\
\text { OTS guidelines: } \\
\text { o Recommend particular disclosures and substantive program procedures. }\end{array}$ \\
\hline $\begin{array}{l}\text { Payment } \\
\text { Network Rules }\end{array}$ & $\begin{array}{l}\text { Visa and MasterCard zero liability and chargeback rules may apply. } \\
\text { See www.usa.visa.com/personal/cards/prepaid/visa_gift_card.html, at note 2, and } \\
\text { www.mastercard.com/us/wce/PDF/PrepaidMCGiftCardUserGuide2007.pdf. }\end{array}$ \\
\hline $\begin{array}{l}\text { Sample Policy } \\
\text { Statements } \\
\text { Concerning } \\
\text { the Scope of } \\
\text { Payment } \\
\text { Network Rules } \\
\text { and Consumer } \\
\text { Protections for } \\
\text { Open-Loop } \\
\text { Gift Cards } \\
\text { Issued by } \\
\text { Financial } \\
\text { Institutions }\end{array}$ & $\begin{array}{l}\text { National City Visa gift cards: "You will not be liable for any unauthorized use of your } \\
\text { Card if you notify us of the unauthorized use on a timely basis in accordance with the } \\
\text { paragraph entitled 'Your Duties and Liabilities' in the Agreement above [requiring that } \\
\text { consumers examine and report unauthorized transactions within } 14 \text { days] or as provided } \\
\text { in the paragraph entitled 'In Case of Errors or Questions About Your Electronic } \\
\text { Transfers' below [providing Regulation E-like protections for erroneous gift-card } \\
\text { charges], whichever is longer. If you want us to issue a replacement Card, you must } \\
\text { know the } 16 \text { digit card number from the lost Card." See https://giftcard.nationalcity.com/ } \\
\text { index.cfm?pageid=g07. } \\
\text { KeyBank Key Possibilities MasterCard gift cards: With regard to unauthorized } \\
\text { transactions, KeyBank maintains that "you may have to bear all loss for an } \\
\text { unauthorized use of your Card. You will have 'Zero Liability' for unauthorized use of } \\
\text { your Card for a non-PIN Card Transaction only if the following conditions are met: (i) you } \\
\text { have exercised reasonable care in safeguarding your Card from the risk of loss, theft or } \\
\text { 'unauthorized use,' (ii) you have not reported two or more other incidents of the } \\
\text { unauthorized use in the preceding } 12 \text { months; and (iii) your Cardholder status or } \\
\text { account is in good standing with us. If you fail to satisfy any of these conditions for a } \\
\text { non-PIN Card Transaction and someone uses your Card without your authorization, you } \\
\text { could lose the entire Card Balance." With regard to errors and merchant disputes, gift- } \\
\text { card holders may be covered so long as KeyBank is notified "no later than } 60 \text { days after } \\
\text { the receipt was issued on which the problem or error appeared." See www.key. } \\
\text { com/html/H-8.1.html. }\end{array}$ \\
\hline State Laws & $\begin{array}{l}\text { State gift-card Laws: } \\
\qquad \begin{array}{l}\text { Can protect consumers who use open-loop gift cards where terms are } \\
\text { decided solely by retail program participants and not nationally chartered } \\
\text { card-issuing financial institutions. }\end{array}\end{array}$ \\
\hline
\end{tabular}

